\title{
A Dialogue on Migration: Residents and Foreign Nationals in Limpopo, South Africa
}

\section{Gwangwa Temperance Ramathetje}

University of Limpopo, Turfloop Graduate School of Leadership, Edupark, Polokwane, PO Box 756, Fauna Park 0787, South Africa

\section{Oliver Mtapuri}

University of Limpopo, Turfloop Graduate School of Leadership, Edupark, Polokwane, PO Box 756, Fauna Park 0787, South Africa Email: oliver.mtapuri@ul.ac.za; mtapurio@edupark.ac.za

\section{Doi:10.5901/mjss.2014.v5n8p573}

\begin{abstract}
This article reflects on the dialogues steeped in a qualitative study which used focus group discussions as well multiple case studies to unpack the experiences of local residents and foreign nationals residing in Mankweng Community in Limpopo, South Africa. The article postulates a migration model of 'positive influences' which states that collaboration; cooperation; technology exchange; skills exchange; capital movement; ubuntu, capacity building; and increased trade between local residents and foreign nationals are key ingredients for co-existence and benefit of all the inhabitants of the Mankweng Community. The model attempts to harness the positive elements which migration provides as the necessary conditions for forging viable migration processes and programmes. This model and the re-framing of migration laws are the major contributions of this article. The new laws that we posit state that for migrants, distance does not matter; migrants seek opportunity irrespective of whether it is in an urban or rural area; migration can be rural to urban, urban to urban; urban to rural and rural to rural; migration flows can be one-way; and contemporary migration both local and international, has become gender-blind (involving males and females) and age-blind involving young children. The article also unpacks the nuances of migration within the context of the Mankweng community by reflecting on the views of both local residents and foreign nationals.
\end{abstract}

Keywords: migration, illegal, push, pull, factors, immigrants,

\section{Introduction}

International theories of migration date back as far as after World War 2. Western theories of migration include conventional migrations (interregional) which result from differences in income and job opportunities (Ahlburg \& Brown (1998 in Hlungwani, 2001). According to Wong (2007) the driving forces behind China's rural to urban migration include: income disparities between the urban and rural areas; over-supply of labour in agriculture, the emergence of township and village enterprises (TVEs) in rural areas, the fall of state-owned companies, and the rise of private enterprises and a modernised market economy as well as policies in some poor provinces that encourage out-migration. The most prevalent migratory movement in South Africa is from rural areas or farms to cities or suburbs in search of a better lifestyle and better job opportunities. Limpopo, as one of South Africa's poorest provinces, has large scale movements of this nature.

Migration and development are twin developmental issues. Most of the causes of human migration, if not all, are development issues such as social-economic, environmental, psychological, political and technological issues. According to the National Geographic Society (2005: 2), human migration is "the movement of people from one place in the world to another for the purpose of taking up permanent or semi-permanent residence, usually across a political boundary. An example of "semi-permanent residence" would be the seasonal movements of migrant farm laborers. People can either choose to move ("voluntary migration") or be forced to move ("involuntary migration")". Migration can happen at different scales: intercontinental (between continents), intracontinental (between countries on a given continent), and interregional (within countries) including rural to urban migration (National Geographic Society, 2005: 1). For the purposes of this study, emphasis is on immigration into Mankweng community of Limpopo.

Immigration has an impact on development issues for both the immigrant and the receiving society. The impact may either be positive or negative. The impacts are also felt in both the receiving and sending societies and countries. 
Mankweng Township has at its core, the University of Limpopo, Turfloop campus, which attracts graduates from all walks of life looking for better job opportunities after completion of their studies. Hlungwani (2001) alludes to the fact that migration, as part of socio-economic processes, is influenced by the state policies. To that end, the findings from this study will inform politicians to formulate policies that help manage and regulate human migration and to device policies that inform future governmental planning at the national, provincial and local government level in order to accommodate current and future migration movements. The positive influence migration model that we posit in this article is helpful in that regard.

\subsection{The Context}

According to the International Organization for Migration (IOM) (2010), in 2010, the number of international migrants in Africa was estimated to be 19 million from 17.5 million migrants in 2005. According to the UN Department of Economic and Social Affairs (DESA), (2009 cited in IOM 2010), Africa hosted about 9 per cent of the total global stock of migrants in that year. This could be an underestimate given the poor migration data available in Africa. Africa is in a state of flux regarding migration dynamics due to conflicts, income inequality and environmental disasters which act as push factors for people to move elsewhere for safety and security from their countries. As such about 40 per cent of all internally displaced persons (IDPs) in the world lives in East and Central Africa (IOM, 2010).

According to the UNDP (2009 cited in IOM, 2010), the total net migration rate during the period 2005-2010 has remained neutral however countries such as Liberia, Burundi and South Africa recorded positive net migration rates while others such as Zimbabwe, Guinea and Sao Tome and Principe, posted negative net migration rates. Overall, the total stock of migrants in Southern Africa was estimated at 2.2 million people in 2010 - of whom 1.9 were hosted by South Africa. As such for South Africa, the stock of international migrants as a percentage of total population was 3.7 per cent in 2010 (IOM, 2010). However, Namibia with $6.3 \%$ is the country with the highest number of migrants as a percentage of the total population (IOM, 2010). South Africa has attracted many migrants because of relatively higher rates of economic growth and the consequences of political and economic crisis in neighbouring countries, especially Zimbabwe (UN DESA, 2009 cited in IOM, 2010). According to Ratha et al., (2009 cited in IOM, 2010) Southern African countries received about USD 1.6 billion in remittances, of which half went to South Africa.

The Organisation for Economic Co-operation and Development (OECD), (2009 cited in IOM, 2010) estimates that 1.2 billion people in Africa will living in urban areas by 2050 (representing $68 \%$ of the population) up from 291 million Africans living in urban areas in 2006 due to higher growth rates in cities and rural-urban migration. The high cost of living in the cities and the temporary nature of rural-urban migration in Africa has led to a reversal of the rural to urban dynamics with a return to rural areas especially in countries like Zimbabwe, Cameroon and Côte d'Ivoire (UN-HABITAT, 2008 cited in IOM, 2010).

According to Zimbabwe National Statistical Agency (ZIMSTAT) \& International Organization for Migration (2010), migration in Africa has become irregular and feminized as women are now migrating on their own, including children. According to Zimstat et al., (2010), Zimbabwe has being going through a rough patch economically since 2000 which witnessed the decline of its gross domestic product (GDP) cumulatively by 46 per cent during the period 2000 and 2007 characterised by a hyperinflation rate of 231 million per cent in July 2008 and increased the rising from 61 per cent in 1995 to 72 per cent in 2003 based on a Total Consumption Poverty Line (TCPL). Zimbabwe emigration patterns have been characterized by informal crossborder movements, movement of highly skilled nationals as well as survival migration of the poor (Zimstat et al., 2010). According to the International Fund for Agricultural Development (IFAD, 2007 cited in Zimstat et al, 2010), formal remittances to Zimbabwe reached USD 361 million in 2007, constituting 7.2 per cent of Zimbabwe's GDP.

According to Zimstat et al., (2010), the problem is compounded by the fact passports are difficult to obtain for many Zimbabweans and the migration policies in SADC countries are more favourable to skilled workers than to those without skills leading to irregular migration of low-skilled Zimbabweans into neighbouring states. This has rendered Zimbabwe to become primarily a country of origin and to a very limited extent, of destination (Zimstat et al., (2010). When looking at more recent emigration flows, two major phases can be distinguished. The first phase corresponds to the years following the country's independence in 1980. As described by Tevera and Crush (2003): "Between 1980 and 1984, 50,000 to 60,000 whites left the country because they could not adjust to the changed political circumstances and the net migration loss was over 10,000 per year." The second phase, from the 1990s to present, shows much more diverse and complex migration patterns than those in the first phase.

According to Kiwanuka and Monson, (2009 in Zimstat et al, 2010), the main countries of destination of Zimbabwean emigration flows are to South Africa, Botswana, Malawi, Mozambique and Zambia with South Africa being 
the principal destination country, followed by Botswana (Centre for Development Enterprise, 2008 cited in Zimstat et al., 2010). As such estimates from various sources suggest that there is a maximum of 1.5 million Zimbabweans in South Africa, who include regular and irregular migrants (Zimstat et al., 2010) with little or no estimates for other countries. The key driving forces of these movements have been economic and employment motivations (Makina, 2007: 2 and 2008: 15; Kiwanuka and Monson, 2009: 25 cited in Zimstat et al., 2010) and as such "cross-border migration is one of the key survival strategies for many households" (Republic of Zimbabwe, 2009a cited in Zimstat et al., 2010). While this section focused on Zimbabweans, there are other nationals from Somalia, Ethiopia, Pakistan, Nigeria, Democratic Republic of Congo and so forth who are being hosted by South Africa as political and economic refugees.

\subsection{The Problem Statement}

A massive number of immigrants left their places of origin and flocked to Mankweng Township. These numbers vary from those who left their places because of push factors like lack of better job opportunities, political upheavals, religious intolerances and poor climatic conditions such as droughts. Immigrants are generally attracted to their place of destination by hopes of better opportunities in terms of employment and living conditions, the promise of asylum and other factors. As such most of the immigrants are from neighbouring countries such as Zimbabwe, Mozambique, Malawi, Congo, Nigeria and so forth. Other immigrants into the area are internal, that is, from other provinces within South Africa. It is a common sight to see people moving from rural villages like Mamabolo, Mothapo, Dikgale and Molepo to Mankweng. The latter group, internal rural-urban migrants, will be looking for better infrastructure like housing, schools, hospitals and other recreational facilities such as sports grounds. Anecdotal evidence also exists suggesting that some are pushed from their places of residence due to socio-cultural reasons like accusation of practicing witchcraft or faction fighting over kingship or chieftainship.

These movements, either from other countries and continents or other provinces, have a profound impact on the development of Mankweng Township in terms of job opportunities, income-generating activities, social relations among inhabitants, political landscape, the environment and technological environments. The consequences to this community have socio-economic, psychological and emotional impacts on both local residents and foreign nationals as this piece shall reflect. The aim of the article is to assess the impact of immigrants on the lives of inhabitants of the Mankweng Community in Limpopo Province of South Africa.

\section{Literature Review}

According to Adepoju (2007) in 2001 the (then) Organization of African Unity held a meeting in Lusaka in which members agreed to mitigate the effects of the brain drain by investing in human development; promote regional cooperation and integration, economic growth and also adopted migration "as an engine for regional cooperation and integration and the socio-economic development of the continent".

Some of the factors that explain migration patterns in Southern Africa include rapid labourforce and population growth, unstable political environments, rising ethnic conflicts, poor commodity prices, general economic decline, desertification and declining arable land (Adepoju, 2007).

According to Adepoju (2007) there are 300000 unfilled vacancies in South Africa that require the skills which the nationals do not have. This big gulf was compounded by the emigration of skilled whites to richer economies at the dawn of independence in 1994.

Panell as quoted by Hlungwani (2001) defines migration as permanent or quasi-permanent relocation of an individual or group of individuals from a place of origin to a place of destination. In an adaption of Kirch, Mukonza (2011) classifies migration as voluntary and forced as follows: voluntary migration includes labour migration (such as temporary contract work); reunification of family members; for educational reasons (student) and undocumented (irregular) migration. Refugees/asylum seekers, internally displace persons (IDPs), environmental migrants and trafficked persons fall under the category of forced migration (Mukonza, 2011).

\subsection{Migration Patterns in South Africa}

Morris and Bouillon (2001:9) point out that historically, immigration to South Africa was to a large extent a white phenomenon. White migrants were given free access to South Africa. However, since 1652, the English speaking Europeans were not readily welcomed into the Afrikaans-dominated National Party. During the $20^{\text {th }}$ century black people from other central and southern African countries were eventually permitted into South Africa albeit under very strict 
conditions (Morris \& Bouillon (2001:9).

According to Morris and Bouillon, (2001:10), the fall of apartheid and the removal of the whites-only immigration laws gave immigrants from other African countries the opportunity to move to South Africa. Furthermore, the deepening economic, social and political crisis in countries like Zaire, Nigeria, Somalia, Senegal, Congo, Zimbabwe and others forced thousands of Africans to migrate to South Africa in the 1990's (Morris \& Bouillon, 2001:10). However, these movements were welcomed by xenophobic attacks, police brutality, crime, violence and even murder of the immigrants. According to Morris \& Bouillon, (2001) it is difficult to ascertain the number of illegal immigrants in South Africa primarily due to the fact that illegal immigrants do not come forward to be counted lest they be deported. Migration patterns in South Africa resemble those in the rest of African continent. People migrate from their places of residence to their destination for various reasons. Sometimes the geographical distance determines the type of movement undertaken.

\subsection{Causes of Migration}

Migration patterns and causes of migration are two related issues that determine one another. Migration is a strategy used by people to run away from their home countries. Migrants from the SADC countries are flocking into South Africa in big numbers. Cross et al., (2006: 272) cite the following as the driving factors of migration:

$\checkmark$ The need to escape conflicts zones;

$\checkmark$ The need to earn more money;

$\checkmark$ Collapsed economies in sending countries;

$\checkmark$ Filling of jobs left by professionals who emigrated overseas;

$\checkmark$ Attraction to destination with most favourable social and political conditions; and

$\checkmark$ Good governance that attracts people, forcing them to leave;

Looking at the above reasons, one is tempted to believe that both push and pull factors are responsible for migratory movements. Migrants, from countries like Zimbabwe, Mozambique and Lesotho come to South Africa with the hope of getting better job opportunities. Political intolerances in countries such as Congo (DRC) and Mozambique forced migrants to leave their countries, for example, the civil war between Frelimo and Renamo between 1975 and 1992 in Mozambique. Such people come to South Africa as asylum-seekers. Wenzel and Tlabela as quoted by Kok et al., (2006) classified their so called cross border migrants from SADC countries into three categories: contract mines migration, voluntary migration and refugee migration. Contract mines migration is the migration of labourers from Southern Africa who were attracted to South Africa by the discovery of gold and diamond. Voluntary migrants left their countries of origin of their own accord in search of better employment and better livelihoods. Refugee immigrants left their countries forcefully because of the political instability and sought asylum in South Africa.

\subsection{Illegal Migration}

Illegal migrants are those people from other countries who enter South Africa without proper documents. There are different categories of these undocumented immigrants:

$\checkmark$ Those who come legally but over-stay when their papers expire; and

$\checkmark$ Those who never had the right documentation, but managed to fraudulently cross the borders.

Such that there is anecdotal evidence that illegal immigrants are the ones who are stealing from the local residents. It is further claimed that is it very difficult to apprehend them as they have no fingerprints in the country. Employers prefer to hire immigrants who are desperate for jobs, and who settle for lower pay. Some farmers even refuse to pay them. Instead they report them to police to be deported to their home countries in an attempt to evade paying them. They are physically and verbally harassed. They are called by derogatory labels like "makwerekwere" and "matšwantle" (foreigners)

In an attempt to check whether illegal immigrants affect the local people's wages, Pickel and Kempner (in Karmiol, 2007:34) discovered that the estimated number of illegal immigration in a state population in America showed no apparent correlation with the median wage for less educated residents in that state. There are studies that depicted the positive impact of illegal immigrants.

\subsection{Impacts of migration}

US researches indicate that the impact of migration on the host country may be either positive or negative depending on the immigrant's level of education and qualifications. The more educated the immigrants, the more positive impact they 
have on the host or receiving countries. Sending countries, on the contrary, will suffer the brain drain and loss of skills and capacity. Pearce's view (in Karmiol, 2007), regarding illegal immigrants is that they impact negatively on American life and accuses them of committing crimes like vandalizing property, burglary, human and drug smuggling. The problem with Pearce's argument is failure to mention the percentage of immigrants involved in criminal activities to back up his assumption, it is an indisputable fact that the immigrants themselves are victims of crime.

\subsection{Brain drain versus brain circulation}

Highly skilled and professional migrants leave their countries to go and work for better salaries in different countries. Countries such as Zimbabwe, Nigeria and Malawi experienced a lot of skills drain to a country such as South Africa. Skilled immigrants in South Africa, according to Morris \& Bouillon (2001:106) include medical doctors, nurses, physiotherapists, laboratory technicians, radiologists, engineers, academics, teachers, computer scientists, bank managers and exportlimport consultants.

Besides being a receiving country of immigrants, South Africa itself also suffered a serious brain drain. Professional health workers, including doctors, engineers and nurses are leaving the country yearly to places like Europe and Australia to look for better paying jobs. Thus, this negative impact of migration is felt in all sending countries.

Furthermore, a shortage of doctors and educators also forced the South African government to replace those who left by those who come from overseas and other areas. This incidence is called brain circulation. Limpopo Province gets its Maths and Science teachers from outside South Africa, as those skills are rare. Reineri (2003) focusing mainly on immigration in receiving South European countries, concluded that well-planned strategies can curb unauthorized immigration and that the presence of immigrants was beneficial to the receiving society. Other studies demonstrated that dedicated policies of co-development are beneficial to both the receiving states, countries of origin and the immigrants themselves (Weil, 2002).

\subsection{Contemporary issues}

According to Bouillon (Morris \& Bouillon, 2001), the immigrants, who ranged from ordinary middle and working class individuals, were primarily engaged in informal trading activities. In South Africa statistics about immigrants are believed to be inflated and encouraging xenophobic attacks. Other studies showed that immigrants provided key professional skills and also helped South African businesses to pursue and open up markets in South Africa and elsewhere (Morris \& Bouillon, 2001:15). The local people claim that foreigners are taking their jobs and women, threatening their livelihoods by benefitting from the Reconstruction and Development Programme and as a result were subjected to violence and hostility. Xenophobia is the hatred and fear that local residents have on the foreigners from other countries. Cross et al., (2006:26) argues that the scarcity of local jobs and high rate of unemployment force local people to have a negative attitude towards the immigrants. A report on xenophobia indicated that newspapers inflate statistics about illegal immigrants, thereby fuelling anger among the local residents. A report in Morris \& Bouillon (2001) showed that South Africans are hostile, prejudicial and stereotyped. It also highlighted that the immigrants are sometimes subjected to crime, violence, police brutality and unemployment, dashing their hopes of getting sanctuary.

\section{Research Methodology}

The study adopted a qualitative design as the most appropriate for this study. The aim of the study is to assess the impact of immigrants on the lives of the members of the Mankweng Community. The units of analysis were local residents and immigrants staying within Mankweng Township. Mankweng Township is situated 30km from Polokwane, the hub of Limpopo province of South Africa. It is the seat of the University of Limpopo's Turfloop campus and a hospital where highly skilled immigrants are working at the university as lecturers and some at the hospital as doctors. In the vicinity are also illegal immigrants who survive on informal trading.

The researchers used non-probability sampling method, as it is "far less complicated to set up, and considerably less expensive "(Cohen, et al., 2007: 113). The researchers used purposive sampling method to select the following participants:

$\checkmark$ Eleven immigrants who were purposively selected from different zones in Mankweng Township as they were the primary informants. These formed the group of foreigner nationals who participated in the first Focus Group Discussion. An additional nine foreign nationals presented their cases to make the case studies 
included in this article. Of interest in a case study is the in-depth information provided by the individual rather than the issue of generalization within a real-life context (Yin, 2009).

$\checkmark$ Fifteen residents of Mankweng. The residents stay together with the immigrants in the community. Among the residents were counselors from ward 31 and 25 as relevant community leaders. These constituted the second Focus Group Discussion.

The separation was necessary to interrogate the issue of migration from the perspective of the two groups. While the researchers purposefully selected these people because of their knowledge and experiences, the flaw of this method is that it is non-representative and findings cannot be generalized to a wider environment.

\subsection{Data Collection methods}

Multiple case studies of immigrants were used in this study. In-depth interviews were carried out necessitating the need for more time with the respondents for probing. Voluntary participation meant that the participants were briefed about the objectives of the study and that they could discontinue their participation at any time during the research. Participants were assured that their information will be treated in confidence. Names that are used in the individual cases are fictitious. Observation was also done to observe the dwellings and the shops of the immigrants. Two focus group discussions were held, one with foreigners and the other with local residents of Mankweng.

Some immigrants who were entrepreneurs could not be interviewed because of language barriers as they could not communicate fluently in English as well as their employees. A number of respondents were found to be clustered in one place as a group, seemingly, for fear of being attacked. At first they were jittery, but after some assurance from the researchers, they opened up. The local residents had their expectations. They wanted to know if there was any promise of a job offer after the interview. They requested feedback after the findings were finalized. They complained that many researchers waste their precious time doing research, but never bothered to give them feedback.

\section{Research Findings}

\subsection{A Foreign Nationals' Perspective}

In the focus group discussion, from our own observation, the age of the local residents ranged between 18 and 50 . A similar age-cohort could be observed among the immigrants. They all represented an active labourforce cohort aspiring to take part in activities of the suburb beneficial to them such as employment, housing and so forth.

A majority of the immigrants were married, a few were single and no-one was cohabiting. This suggests that it is not only married people who migrate, but the singles also do leave their families to try their luck in South Africa.

In the Focus Group Discussion, most of the immigrants said they have two to four people to feed. The more the dependants, the bigger the responsibility, and the more the urge to look for better job opportunities.

\subsubsection{Country of origin and town}

Most of the immigrants who participated in this study were Zimbabweans coming from Harare, Norton and Kadoma. This was followed by Ethiopians and Nigerian nationals. Zimbabwe accounted for the majority possibly because of its proximity to South Africa. Migration costs might be affordable to most of the immigrants. Another reason might be laxity of law enforcement at the border gates. Ethiopia and Nigeria are far from South Africa.

\subsubsection{Employment Status}

Many of the immigrants said they were self-employed, including the semi-skilled and the unskilled immigrants. They said they survived mostly by selling goods. Most of them carry the goods on their shoulders and move from house to house selling, while others sell their merchandise at street corners. Those who are self-employed have been in Mankweng for the past 5 to 10 years. No-one is unemployed.

\subsubsection{Migration profile of the immigrants}

The Ethiopians explained that they come from rural areas where they depended on cultivating the land for survival and on average they have been in South Africa for between $6-10$ years. Among the immigrants was a computer technician and 
computer analyst, office administrator and leadership consultant, caterer, beauty therapist, hairdresser and dress designer and people who could do arts and crafts as well as hair cutting, braiding and relaxing.

\subsubsection{Availability of service delivery}

The services that are mostly available to both residents and immigrants are: electricity, tap water, hospitals, clinics and police station while RDP houses are available to the residents only. These are the same services that attracted immigrants into South Africa. The immigrants said they were renting backrooms or shacks with their partners. They considered the quality of electricity and tap water to be good but they also said electricity is a luxury to some who cannot afford to pay for this service.

\subsubsection{Using same schools}

From the discussion, it is difficult to ascertain the extent to which immigrants use the same schools with residents or not. Those with children would surely use them. However, many immigrants claimed they had left their spouses and children in their home countries. This suggests that perhaps only a few immigrants were using the same schools as residents to educate their children only in instances where their status has been regularised. Asylum seekers are allowed to work and study in South Africa.

According to the researchers' observations, immigrants even make use of old, uninhabited houses and buildings as shops. Some immigrants, on the other hand, have rare skills not found among the residents, for example, computer technicians, Maths and Science teacher, doctors (specialists) and other professions. Apparently immigrants move in groups, for fear of being attacked or because of the networks that they have established among themselves in the township. Another observation the researchers made was that the immigrants form partnerships to boost one another financially such that they accumulate money and, for instance, buy one car to be utilized by the whole group.

\subsection{A Residents' Perspective}

A majority of the residents never married. Strikingly, they were those respondents who were married, but said were "children", because they are still staying with their parents. They indicated that they are still dependent on their parents for residence. This might also be caused by either lack of employment or lack of adequate housing from the Department of Housing. The reason could be that as with other employees in South Africa, the situation is that some of them do not qualify for proper houses because of their low wages. This is the group that usually stays with parents or rents backrooms and shacks for a good part of their lives.

\subsubsection{Household size}

In the Focus Group Discussion, most residents said they stay in households with about 6 people or more. It shows that residents have bigger families than the immigrants. From the discussions, the researchers' estimate shows that about a quarter of the residents were unemployed. The rest were also self-employed or employed.

\subsubsection{Reasons why immigrants leave their countries}

When asked about the reasons that forced immigrants to leave their country, the residents mentioned that they think the immigrants left because of poor economies in their home countries as well as escape from violence. Others mentioned educational opportunities in South Africa and joining family or friends as pull factors to South Africa. Residents in the FGD also mentioned that the political stability in the country and good governance are attracting those who come from countries characterized by wars and turmoil to seek refugee in South Africa.

\subsubsection{Type of migration}

Most of the residents think that immigrants move from rural to urban areas. Some residents said for as long as there are no strict policies prohibiting immigrants to stay in South Africa, they will stay permanently forgeting where they come from. Such that some respondents said the immigrants have found their greener pastures in South Africa. Some said 
immigrants were taking over some economic activities meant for local residents. Only a few residents said they think immigrants will go back to their home countries as soon as things get back to normal in those countries.

\subsubsection{Offering jobs to residents}

When asked whether the immigrants offer jobs to the residents, a few agreed. According to the residents, most of the immigrants are self-employed; selling goods and looking for better jobs themselves. Immigrants are so desperate for jobs to an extent that they end up settling for menial and poor paying jobs. Residents argued that because of this, they will be denying local residents an opportunity to ask for decent work and better pay. They also noted that some employers take advantage of the vulnerability of the immigrants by refusing to pay them as the poor immigrants keep it to themselves for fear of being deported to their homes/countries.

According to one elderly man, the immigrants are involved in fraudulent practices like stealing women's identity documents and marrying them without their knowledge. Residents said that only a minority of immigrants is offering jobs to residents. Residents also mentioned that some immigrants trade under the names of the local residents after realizing that if they trade under their own names, their merchandise may be looted or they may face both physical and verbal abuse.

\subsubsection{Using same health care facilities}

A sizeable number of local residents were saying that immigrants use the same hospitals and clinics as the residents and this puts a lot of strain on the facilities and state coffers. A majority of residents feel that the immigrants are overburdening government services and programmes, especially in health. Residents acknowledged that a remarkable positive contribution by immigrants in the health services sector can be seen in hospitals especially in the rural areas where most of foreign doctors are working. Residents claimed these foreign doctors were replacing South African doctors who emigrate overseas. Residents admitted that this was a positive gesture.

\subsubsection{Sharing skills with immigrants}

Residents said that no-one can dispute the fact that professionals from other countries have some of the rare skills in education, health and science. Residents said that the fact that South Africa outsources Maths and Science teachers from countries like Zimbabwe bears testimony to this. Some of the residents indicated that residents acquire some skills from the immigrants and vice versa. This corroborated by a lady from Zimbabwe, a professional hair dresser, who said that she also gained a lot of experience and skills from her South African colleagues at work. The salon owner, a South African, continued to say South Africans come to work late and yet they are the first ones to knock off. She also accused the local residents of laziness and disloyalty.

\subsubsection{Taking jobs from residents}

In the Focus Group Discussion it emerged that about a third of the residents agreed that immigrants were stealing their jobs and their spouses. Immigrants were also accused of depriving local residents of the opportunity to get well-paying jobs. According to residents, these fears and accusations against immigrants engender feelings of resentment among local residents such that some turn a blind eye on the positive contributions being made by immigrants. Mixed reactions were made on this matter as this excerpt illustrates:

How can the immigrants improve my life when they cannot improve their own lives? This is totally ridiculous. You cannot give something you don't have. Send these people back to their homes before they cause more havoc.

One resident said the immigrants were responsible for causing illnesses like HIVIAIDS, tuberculosis and many other sexually transmitted diseases. "They (immigrants) are the carriers of "Ebola" and "Swine flu", an angry resident retorted.

\subsection{Case Studies}

The following case studies build up the contribution of immigrants to the lives of the residents of Mankweng and through an exposition of their life journeys. 


\subsubsection{Case study 1: Abebo, Ethiopian}

A male Ethiopian, Abebo stated that he escaped violence from Addis Ababa and was looking for a better lifestyle. He is from a rural area where they survived by farming and selling agricultural products. He is self-employed and sells goods such as curtains, blankets and sheets. He said he fell in love with Mankweng. He was interested in getting permanent residence. He said most of the immigrants utilized services like electricity, water and the local police station. He claimed he was generally well, but admitted that he would visit clinics and hospitals, when the need arises. He said he did not use local schools because he had left his spouse and children at home. He stays in a rented backroom and some of his country men were staying in shacks. The excerpt below encapsulates his frustration with the police:

The police refused to help me when my merchandise was stolen from my spaza shop. I had information to help the police to catch the thief. They just dragged their feet - they literally refused.

Abebo disagreed strongly about the fact that he was stealing a job from a South African.

I pray time and again for peace to prevail in South Africa. I want nothing else but to work. My other name Habtamu means rich man. Maybe I will be rich one day.

He said he also prays for an opportunity to get a real church building as at the moment they are using a pre-school for church services.

He also complained:

It's very difficult for us to acquire property. It's also difficult to buy things like TVs and cars on account. They think we all have criminal records, selling drugs. It makes us feel bad and isolated.

He accuses South Africans of laziness.

If you give them a job, they run away after the first month's pay. They seem to enjoy their comfort zone brought about by social grants. What they know better is to make kids for more social grants.

\subsubsection{Case study 2: Abe, Nigerian}

Abe, a Nigerian man is an analytical computer technician who builds and repairs computers. He is also a carpenter and a technician for business machines. He was cool and relaxed during the whole interview. He married a South African woman. He said he does not intend to stay permanently because he is interested in exploring other parts of the globe. He acquired some computer skills in South Africa - Mankweng. His claimed that his reason for coming to Mankweng was to impart skills to local residents.

He employed eight people, which he strongly believed improves the lives of the residents in Mankweng. The only two public services he benefits from are electricity and tap water. When asked whether he is taking people's jobs, Abe said: "The least I can do is to take other people's jobs. I am sharing my skills with them. In fact, my skills are very rare and no one will compete with me here."

\subsubsection{Case study 3: Morris, Nigeria}

Morris from Nigeria came with his wife and children. He is self-employed and shares a shop with Abe. He said his main reason for coming to South Africa was to pursue missionary work. He said he does not intend to stay permanently in South Africa.

My passion and calling is to develop people in other parts of the globe spiritually. I don't want to compromise my vision and passion.

Morris is a clergy man, computer technician, leadership consultant, and a management consultant. He said he is also doing arts and crafts. He reiterated that he is offering people jobs and does not steal jobs from people. He said he furthered his computer studies in South Africa. 


\subsubsection{Case study 4: Lorraine and Mary, Zimbabwean females}

The two female respondents from Norton in Zimbabwe said they have the same skills of braiding and relaxing hair. They are employed at the same hair salon in Mankweng. Their average age is 22. Lorraine, is married and she left her family in Zimbabwe. She wishes to get permanent citizenship as she sees Mankweng as a place with better work opportunities. Her other skills are hotel management and catering

Her friend Mary is an office administrator by profession. Due to lack of employment, she learnt braiding and relaxing in Mankweng. When asked about her contribution to the lives of the residents, she claimed that she is making a positive contribution to the economy of Mankweng and asserted that let there be rules to regulate movement of people for the benefit of all as the Europeans do.

\subsubsection{Case study 5: Joyce, Zimbabwean female}

Joyce, a female (37 years) also from Harare in Zimbabwe, is renting two rooms. She is a self-employed hair dresser. She said she does not regret leaving her family behind. She has been working in Mankweng since 2000. She also does not intend to live permanently in South Africa.

Home is always best. If economic conditions improve, l'll gladly go back to my country Zimbabwe where I belong. There is no electricity where she stays, but she talks well about the local people.

I like it here. I feel like I'm part of this community. When they have functions like weddings or bereavements, they invite me to join them. I hope to get employment as a fashion designer one day - which is my actual profession.

\subsubsection{Case study 6: Artus, Zimbabwean widow}

Artus, a 38 year old widow from Kadoma, Zimbabwe survives by selling curtains and pottery. She said she does not make a fortune from selling, but it puts bread on the table. She does not want permanent citizenship. She is fortunate to live in an Reconstruction and Development Programme (RDP) house belonging to one of the residents, without paying a single cent in rent. She hopes to get her own house one day. An RDP house is a low cost house built by the government for the poor. She is not certain how she contributes to the socio-economic development of Mankweng as she felt that she has no special skill to share with the local people except pottery and claims trade is important between countries even at grassroots level.

What I know for sure is that I have a fine relationship with the people here. I really enjoy my stay here. A sign of their humanity/ubuntu.

\subsubsection{Case study 7: Gladys, Zimbabwean female}

Another Zimbabwean lady, Gladys, is 40 years old and single and said she possessed a technikon diploma. Currently, she is a qualified beauty therapist who works for someone. Her main reason for leaving her country was the desire for a change of environment. She is not sure whether she wants to settle permanently or not. She said fate will determine her future. She has also adopted a young boy aged 13 who had come to South Africa with a group of other children.

Another Zimbabwean female, Chipo, aged 30 and single, was the most educated of all the respondents. Her sole reason for coming to Mankweng was to further her studies at the University of Limpopo. She is currently studying on a part-time basis towards her Masters degree. She is also a Maths and Science teacher at a local school. She intends to get married to a South African and settle permanently, 'so that her children do not suffer like her'.

I've been head-hunted to come and teach Maths and Science at a school here. Local teachers did not qualify for the post, and it makes me feel like an asset.

\section{Towards a Model of "Positive Migration Influences"}

In this article we posit a model of positive migration influences which attempts to harness the positive influences located in the intersecting area of diagram 1 below. The diagram reflects the (positive and negative) views both of local residents and foreign nationals regarding migration. The intersection reflects the area of concurrency or positive influences of the migration model.

These positive influences include:

- Collaboration; 
- Cooperation;

- Technology exchange;

- Skills exchange;

- Capital movement;

- Capacity building;

- Increased trade; and

- Spirit of ubuntu/humanness.

The model says the more people collaborate, cooperate, exchange skills and technology and trade among each other even at the local level has profound 'positive influence' for co-existence among nationals of different countries.

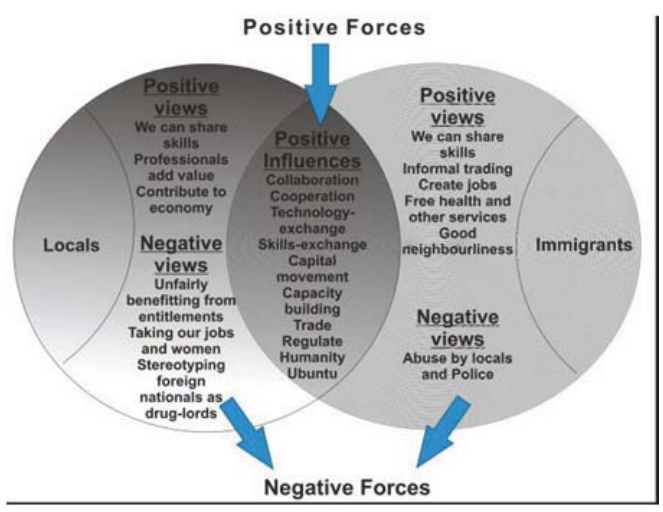

The negative influences would be unimaginable and would possibly include disharmony, violence, xenophobia and so on. The importance of this model lies in positing the influences worthy of consideration in national, regional and global documents as necessary conditions for viable migration between nationals and governments of different states. It can be admitted upfront that the conditions are necessary and perhaps not sufficient to explain all the required conditions for all viable migration processes devoid of the negative influences.

\section{Discussion}

Since 1994 elections, a favorable political climate has made South Africa a haven for immigrants seeking asylum and opportunities in life. Other pull factors that are attracting people to South Africa are better employment opportunities, better education and better health care facilities. In actual fact, pull factors like better employment are a direct answer and remedy to poor employment opportunities that drove immigrants away from their countries. Push factors and pull factors are interrelated and interwoven.

It is possible that the immigrants may leave their country because of a combination of reasons. It can be surmised that if a country offers poor economic opportunities to its citizens, this will result fewer educational opportunities and vice versa. As a result, public services like housing, transport, electricity and water tend to also be poor. Thus, the overall quality of life of the citizens tends to leave much to be desired as one poor situation breeds another.

Historically, labour migration was a male domain, but now things have changed as females are now migrating to look for work in their own right. Most of the movements by immigrants are from rural areas where there are no adequate services to urban areas where these services are in abundance. Residents fear that immigrants will decide to stay permanently and swamp the country. Residents were blaming immigrants for some social ills in the township like crime, theft, communicable diseases like HIVIAIDS, TB especially from the unemployed and the unskilled residents who accused of stealing their jobs.

Most of the immigrants are self-employed and hard-working while they perceived local people as lazy. The immigrants blamed the residents for their laziness or work-shyness but big appetite for the social grants doled by government on a monthly basis.

There is evidence that the most skilled immigrants contribute positively to the development of Mankweng as the 
receiving society. Immigrants also hire local residents to work in their businesses. Immigrants impart knowledge, skills and labour to the residents. These skills are helpful in improving the quality of life of the residents of Mankweng. Furthermore, professional immigrants also pay their taxes. Xenophobia is a mindset of bad elements in society such as thugs and other criminals who convert the pandemonium to achieve their own ends.

In conclusion, Dye (2008:197) cited in Mukonza (2011) claims that immigration policies are driven by the elite in a elite-mass model in which the elites direct public policy while the masses are remain ill-informed and consequently indifferent, thus, allowing them to recruit cheap labour from outside the country. Mukonza (2011) argues that there is no proof that the elite pursue such policies knowing that the poor will become the victims of such a policy. We also posit a mass-elite model, which reverses the roles in which the masses through acts of violence got the Government to act by establishing a new regime in 2011 for the registration of Zimbabweans (as a pilot) to normalizing/regularizing their stay and employment in the country. In this vein, Government is subsumed to be within the context of the elite.

Mukonza (2011: 1394) recommends,

an integrated approach to tackling xenophobia in South Africa. Literature has shown that the 2008 violence against immigrants is intertwined with a variety of socio-economic challenges bedeviling the country. The government needs to expedite service delivery and job creation, particularly to the poor sections of society. It is also important that international migration be treated as a developmental issue, and captured in key national policy documents.

According to the National Geographic Society (2005), in the 1880s, Geographer E.G. Ravenstein developed a number of migration 'laws' which form the basis for modern migration theory anchored on the following principles:

- Most migrants travel only a short distance.

- Migrants traveling long distances usually settle in urban areas.

- Most migration occurs in steps.

- Most migration is rural to urban.

- Each migration flow produces a movement in the opposite direction ("counterflow").

- Most migrants are adults.

- Most international migrants are young males, while more internal migrants are female.

We re-frame the laws of migration as postulated by Geographer E.G. Ravenstein and posit our own laws as follows:

- For migrants, distance does not matter;

- Migrants look for opportunity irrespective of whether it is in an urban or rural area; space of peace, opportunity and tranquility is important to them;

- Migration is location blind - rural or urban - it depends on where one is coming from;

- Migration can be rural to urban, urban to urban depending on the degree of 'urbanization'; urban to rural and rural to rural;

- Migration flows can be one-way depending on the circumstances e.g. war;

- Migration, local and international, has become gender-blind (involving males and females) and age-blind involving young children;

\section{Conclusions and Recommendations}

From the findings given above, the following conclusions and recommendations are made:

In cases where South African needs the expertise that the immigrants may have, the systems must facilitate the process and not serve as an impediment as most skilled immigrants contribute positively to the development of the country. Again, the government must conclude bilateral partnership programs with the sending countries such as Zimbabwe, Mozambique, Nigeria and Ethiopia to manage future migration movements especially of undocumented people. These multilateral programs should attempt to address or improve the conditions that force the migrants to leave their countries where possible. At present the border gates are porous, allowing illegal immigrants to come into the country. This makes it difficult for governments to document the number of all migrants. Education programmes targeting the local residents may be necessary to disabuse them of the notion of foreign nationals as parasites without understanding their backgrounds, histories and the positive impacts they may make in their lives. Furthermore, foreign nationals must be educated on the need to regularize their stay and not to engage in crime which is tarnishing their image. Those unemployed South Africans with skills but unemployed should take the initiative to create jobs for themselves and others and not to wait for the government to create jobs for them as the foreign nationals are doing lest this leaves residents with skills that are dormant and under-utilized. 
In this article the researchers dialogued with both local residents and foreign nationals residing in Mankweng in Limpopo, South Africa. Local residents consider some foreign nationals especially the professionals as adding value to the community, while some still perceive foreign nationals as a menace in terms of 'stealing' from them public goods and services entitled to citizens as well as job and other opportunities that they believe are rightfully theirs. Foreign nationals consider the local residents as less industrious than them and highly dependent on various grants doled out by Government. Based on the findings, the researchers postulated a migration model of 'positive influences' which attempts to harness the positive elements that migration provides. The amplification of these elements may obviate violent acts among the residents of Mankweng community, both local and foreign nationals to bring about a cohesive community.

\section{References}

Adepoju, A. (2007). Migration in Sub-Saharan Africa, Available at http://www.sweden.gov.se/content/1/c6/08/88/66/730473a9.pdf ( Accessed 2 July 2012).

Cohen, L., Marion, L., \& Morris, L.L., (2007). Research Methods in Education. London: Routledge.

Cross C., Gelderblom D., Roux, N., \& Mafukidze, J. (2006). Views on migration in Sub-Saharan Africa. Proceedings of an African Migration Alliance workshop. Cape Town: HRSC Press.

Hlungwani, M.C. (2001). Parental Guardian Labour Migrancy and the Learners School Performance: A Case Study in Mamabolo Area, Sub-district of Mankweng in the Northern Province. Unpublished mini-dissertation for MDEV. University of the North.

International Organization for Migration. (2010). World Migration Report 2010, The Future of Migration: Building Capacities for Change. ISSN 1561-5502. Available at http://publications.iom.int/bookstore/free/WMR_2010_ENGLISH.pdf (Accessed 28 March 2013).

Karmiol, S.M. (2007). Illegal Immigration. Mishawaka: Green Haven Press.

Kok, P., Gelderblom, D., Oucho, J.O., \& Van Zyl. (2006). Migration in South and Southern Africa. Dynamics and Determination. Cape Town: HSC Press.

Morris, A., \& Bouillon, A. (2001). African immigration to South Africa: Francophone migration of the 1990's. First English Edition. Pretoria: Protea \& IFAS .

Mukonza, R. (2011). Immigration and refugee policies: unpacking policy dilemmas in South Africa, Journal of Public Administration, 46 (2), 1384-1396.

National geographic Society. (2005). What is Human Migration. Available at http://www.nationalgeographic.com/xpeditions/lessons 109/g68/migrationguidestudent.pdf (Accessed 2 July 2012).

Reineri, E.(2003). Immigration and the Under Economy in New Receiving South European Countries: Manifold Negative Effect. International Review of Sociology, 13 (1), 117-128.

Weil, P. (2002). International Migration. Oxford: Blackwell Publisher.

Wong, D.F.K., Li, C.Y., \& Song, H.X. (2007). Rural migrant workers in urban China: living a marginalised life. Available at http://onlinelibrary.wiley.com/doi/10.1111/j.1468-2397.2007.00475.x/full (Accessed 11 June 2012).

Yin, R.K. (2009). Case study research. Design and Methods. Fourth Edition. Los Angeles: Sage Publications.

Zimbabwe National Statistical Agency (ZIMSTAT) \& International Organization for Migration (2010). Migration in Zimbabwe: Migration Profile 2009, Harare: ZIMSTAT Publisher. 